\title{
Trilostane Treatment of Canine Alopecia $X$ in an American Pit Bull Terrier
}

\author{
J. KOLEVSKÁ ${ }^{1}$, V. BRUNCLÍK ${ }^{1}$, L. BARTOŠOVÁ ${ }^{2}$, M. SVOBODA ${ }^{1}$ \\ ${ }^{1}$ Clinic for Dog and Cat Diseases, Faculty of Veterinary Medicine, University of Veterinary and Pharmaceutical \\ Sciences, Brno, Czech Republic \\ ${ }^{2}$ Department of Human Pharmacology and Toxicology, Faculty of Pharmacy, University of Veterinary \\ and Pharmaceutical Sciences, Brno, Czech Republic
}

Received July 17, 2006

Accepted November 29, 2006

\begin{abstract}
Kolevská J., V. Brunclík, L. Bartošová, M. Svoboda: Trilostane Treatment of Canine Alopecia X in an American Pit Bull Terrier. Acta Vet. Brno 2007, 76: 113-120.

This paper describes the case of a one-year-old female American Pit Bull Terrier, presented with the history of progressive baldness. The initial clinical signs were demonstrated by symmetric, primarily non-pruritic alopecia that began in the perineal, genital, and ventral abdominal regions and propagated cranially to the thorax and to the neck. Based on physical and dermatological examination, laboratory findings, and results of skin biopsy, a hormone-responsive dermatosis was diagnosed. Once hypothyroidism and hyperadrenocorticism were ruled out, with the help of hormonal tests, the diagnosis was specified as alopecia X. The first treatment option recommended for the patient and subsequently completed was ovariohysterectomy. After three months, the owner reported improvement; the dog was almost covered with hair. The patient was presented again six months later, showing almost the same dermatological symptoms, which, however, were of a more striking character than before ovariohysterectomy. Again a series of hormonal tests was carried out. Considering the elevated basal and post-adrenocorticothropin stimulation progesterone concentrations, the final aetiology of the disease was determined as an adrenal sex hormone imbalance. Therefore trilostan therapy was initiated. The trilostan dosage of $8 \mathrm{mg} / \mathrm{kg} / \mathrm{day}$ was divided and given 2 times daily. This treatment led to complete hair regrowth in the dog within four months. No adverse effects associated with trilostane were recognized.
\end{abstract}

Congenital adrenal hyperplasia-like syndrome, progesterone, adrenal sex hormone imbalance

Causes of aquired alopecias are numerous in dogs and include infections, self-inflicted hair loss (from hypersensitivities or parasitism), endocrinopathies, follicular dysplasias, etc. Some endocrinopathies (e.g. hypothyroidism, hyperadrenocorticism, hyperestrogenism, pituitary dwarfism) are well characterized clinically and the hormonal implication is fully understood. However, many alopecic disorders that clinically resemble endocrinopathies such as the various types of follicular dysplasias (e.g. canine recurrent flank alopecia, alopecia-X, colour dilution alopecia, black hair follicular dysplasia), or other dermatoses possibly associated with sex hormones of gonadal or adrenal origin, the hormonal aetiology is uncertain (Paradis 2004).

Alopecia $\mathrm{X}$ is the name many veterinary dermatologists are now using to refer to the following diseases: pseudo-Cushing, adult onset growth hormone deficiency, hyposomatotropism of the adult dog, growth hormone responsive alopecia, castration responsive dermatosis, gonadal sex hormone alopecia, sex hormone growth hormone dermatosis, hypogonadism in intact males, biopsy responsive alopecia, post-clipping alopecia (of plush-coated breeds), adrenal sex hormone imbalance, adrenal hyperplasia syndrome, Lysodren responsive dermatosis, follicular dysplasia of Nordic breeds, Siberian Husky follicular dyplasia, follicular growth dysfunction of the plush-coated breeds and

Address for correspondence:

MVDr. Jana Kolevská, Ph.D.

Clinic for Dog and Cat Diseases

Faculty of Veterinary Medicine

University of Veterinary and Pharmaceutical Sciences

Palackého 1 -3, 61242 Brno, Czech Republic

Phone: +420723349859

E-mail:kolevskaj@email.cz

http://www.vfu.cz/acta-vet/actavet.htm 
black skin disease of Pomeranians. The diversity in names is merely descriptive and based upon the difference in endocrine evaluation clinical responses to various therapeutic modalities (Paradis 1999, 2002, 2004).

The first clinical signs include loss of primary hairs (with retention of secondary hairs) in the friction areas (around the neck, caudomedial thighs and tail). Gradually, all hair is lost in those areas and eventually the trunk primary hairs are also lost. The remaining coat thus resembles that of a puppy (or a very old sheep-skin rug). Within a certain period (from several months to years) the secondary hairs become sparse, and the remaining hair coat can be affected by hyperpigmentation of the exposed skin and/or colour change ( $\mathrm{Schmietzel}$ 1999; Paradis 2002; Paradis 2004).

The head and legs are usually spared. A common finding in this syndrome is a tendency to regrow hair at the biopsy site following skin biopsy or other external traumatic stimuli skin scraping, sunburn (Paradis 2002).

The age at onset is from 9 months to 11 years (more common in young adults). It is more frequently observed in neutered dogs. The Nordic breeds with plush coat such as Pomeranians, Chow Chows, Keeshonds, Samoyeds, Malamutes, and Huskies are more prone to develop the syndrome. Miniature Poodles also seem more susceptible to this disorder. The presented paper analyses the course of the above described disease in a oneyear-old female American Pit Bull Terrier. The aetiology of alopecia X in this case was supposed to be an adrenal sex hormone imbalance (Paradis 2000).

\section{Materials and Methods}

Physical examination

A one-year-old female American Pit Bull Terrier was presented at the Clinic for Dog and Cat Diseases, Faculty of Veterinary Medicine, University of Veterinary and Pharmaceutical Sciences Brno. A complete physical examination of the patient was carried out.

Laboratory examinations

Blood samples were collected and preserved with EDTA prior to haematological examination with Beckman coulter ACT 8. Differential blood count was evaluated after staining with standard May-Grünwald and GiemsaRomanowski stains. Biochemical examination was carried out in serum after standard centrifugation. Cobas Mira $\mathrm{S}$ analyser was used to determine biochemical indicators. Cortisol, total thyroxine $\left(\mathrm{tT}_{4}\right)$, free thyroxine $\left(\mathrm{fT}_{4}\right)$, canine thyrotropin (cTSH), estradiol, progesterone and testosterone levels in serum were determined by chemiluminiscence immunoanalysis (Immulite 2000 Estradiol, Progesterone, Total Testosterone, Total $\mathrm{T}_{4}$, and Immulite cTSH, Diagnostic Products Corporation). Sensitivity of estradiol determination was 37 pmol/1, progesterone $0.6 \mathrm{nmol} / 1$, total testosterone $0.3 \mathrm{nmol} / 1$, total thyroxine $5 \mathrm{nmol} / 1, \mathrm{cTSH} 0.03 \mathrm{ng} / \mathrm{ml}$. Calibration range upper limit was $7342 \mathrm{pmol} / \mathrm{l}$ (estradiol), $127 \mathrm{nmol} / \mathrm{l}$ (progesterone), $55 \mathrm{nmol} / \mathrm{l}$ (total testosterone), $309 \mathrm{nmol} / 1$ (total thyroxine), $12 \mathrm{ng} / \mathrm{ml}$ (cTSH).

Low-Dose Dexamethasone test was performed and urine cortisol/creatinine ratio - UCCR (Rijnberk 1988) measured to rule out hyperadrenocorticism.

Adrenocorticothropin hormone (ACTH) stimulation test was also carried out. Synthetic ACTH (Synacthen) was administered by intramuscular injection at a dose of $0.25 \mathrm{mg}$ pro toto. Basal and post-stimulation levels of progesterone were measured. The ACTH stimulation test was performed 3 hours after administrration of of trilostane.

Immunoreactive cortisol levels in urine were measured using fluorescence polarisation immunoassay - FPIA (TDx system) method with urine extraction (Abbott comp., No 9116-60). Dichlormethan was used for urine extraction. Creatinine levels were also measured in each urine sample. The results obtained were used to calculate the urine cortiol/creatinine ratio (UCCR).

The skin biopsy was carried out. Tissue specimens were fixed in formalin and routinely processed and paraffin embedded. The slides were stained with haematoxylin and eosin.

Therapy

The patient was treated with trilostan $\left(V_{\text {Vetoryl }}^{\circledR}\right.$ cps. $30 \mathrm{mg}$ Arnolds). The therapeutic dose was $4 \mathrm{mg} / \mathrm{kg}$ two times daily.

\section{Case Description and Results}

One-year-old female American Pit Bull Terrier was presented at the Clinic for Dog and Cat Diseases with the anamnesis of progressive baldness. The initial loss of hairs began 
in the perineal, genital and ventral abdominal regions and propagated cranially to ventral regions of thorax and the neck (Plates XII, XIII, Figs. 1-3). The hair coat of the presented patient was of low quality, imbricated, hyperpigmented with apparent frayed and brittle hair tips. The owner of the patient did not claim the presence of pruritus. Dermatological examination was carried out, and blood taken for basic haematological and biochemical tests. Skin scraping test proved negative, and the haematological and biochemical test results did not display any noticeable differences from the reference range (Table 1). After the skin biopsy, the result of the dermatohistopathologic examination was following: Epidermis - mild basket weave hyperkeratosis, epidermal atrophy in the whole range. Dermis - thinner on the whole, scarce "collagen fibres", and of lighter colour. Adnexa - atrophy, dilatation, keratosis of follicles, intact follicles, predominance of telogen hair follicles, and great number of follicles demonstrating trichilemmal keratinization (flame fibres). Otherwise normal histopathological finding. Subcutis - normal finding. Final result of skin biopsy - atrophic hormonal dermatosis.

Table 1. Haematological and biochemical values in the presented dog

\begin{tabular}{|c|c|c|}
\hline Parameter (unit) & $\begin{array}{l}\text { Presented } \\
\text { Patient }\end{array}$ & Reference range \\
\hline Haemoglobin $(\mathrm{g} / \mathrm{l})$ & 162 & $120-180$ \\
\hline Haematocrit (1/1) & 0.49 & $0.37-0.55$ \\
\hline Erythrocytes $\left(10^{12} / 1\right)$ & 7.42 & $5.4-8$ \\
\hline Leukocytes $\left(10^{9} / 1\right)$ & 9.2 & $6-18$ \\
\hline Neutrophils bands $\left(10^{9} / 1\right)$ & 0.184 & $0-1$ \\
\hline Neutrophils mature $\left(10^{9} / 1\right)$ & 5.428 & $3-11.4$ \\
\hline Lymphocytes $\left(10^{9} / 1\right)$ & 3.312 & $0.8-3.8$ \\
\hline Monocytes $\left(10^{9} / 1\right)$ & 0.184 & $0-1.8$ \\
\hline Eosinophils $\left(10^{9} / 1\right)$ & 0.092 & $0-1.9$ \\
\hline Total protein $(\mathrm{g} / \mathrm{l})$ & 59.7 & $55-75$ \\
\hline Albumin $(\mathrm{g} / \mathrm{l})$ & 29.3 & $23-34$ \\
\hline Glucose $(\mathrm{mmol} / \mathrm{l})$ & 5.2 & $3.3-7.0$ \\
\hline Creatinine $(\mu \mathrm{mol} / \mathrm{l})$ & 50.6 & $20-110$ \\
\hline Urea $(\mathrm{mmol} / \mathrm{l})$ & 8.5 & $3-9$ \\
\hline $\operatorname{ALP}(\mu \mathrm{kat} / \mathrm{l})$ & 1.32 & $0.1-1.5$ \\
\hline $\operatorname{ALT}(\mu \mathrm{kat} / \mathrm{l})$ & 0.65 & $0-1$ \\
\hline AST $(\mu \mathrm{kat} / \mathrm{l})$ & 0.58 & $0-1$ \\
\hline Triglycerides (mmol/l) & 0.86 & $0.5-1.7$ \\
\hline Cholesterol $(\mathrm{mmol} / \mathrm{l})$ & 4.34 & $2.7-7$ \\
\hline Sodium $(\mathrm{mmol} / \mathrm{l})$ & 145 & $140-158$ \\
\hline Potassium (mmol/1) & 4.2 & $3.8-5.8$ \\
\hline Calcium (mmol/l) & 2.7 & $2.2-2.9$ \\
\hline Phospohorus (mmol/1) & 1.8 & $0.5-2.6$ \\
\hline Estradiol (pmol/1) & 80 & depends on the phase of the ovarian cycle \\
\hline Progesterone $(\mathrm{ng} / \mathrm{ml})$ & 0.8 & depends on the phase of the ovarian cycle \\
\hline $\begin{array}{l}\text { Post ACTH stimulation } \\
\text { progesterone }(\mathrm{ng} / \mathrm{ml})\end{array}$ & 8.4 & not determined \\
\hline Testosterone $(\mathrm{nmol} / \mathrm{l})$ & $<0.69$ & not determined \\
\hline Canine thyrotropin (ng/ml) & 0.28 & $0.03-1.0$ \\
\hline Total thyroxine $(\mathrm{nmol} / \mathrm{l})$ & 30 & $20-40$ \\
\hline $\mathrm{UCCR} \times 10^{-6}$ & 7 & $<10$ \\
\hline
\end{tabular}

The dermatological examination findings considered, the next diagnostic step of hormonal tests was taken. Parallel concentration of total thyroxine $\left(\mathrm{tT}_{4}\right)$ and canine 
thyrotropin (cTSH) was measured. The Low-Dose Dexamethasone test followed, UCCR and basal concentration of estradiol, progesterone and testosterone were determined. ACTH stimulation test was performed too. Basal and post stimulation levels of progesterone were measured. Concentrations of $\mathrm{tT}_{4}, \mathrm{cTSH}$, estradiole, and testosterone proved to be within reference range, UCCR was in between $5-7 \times 10^{-6}$, the Low-Dose Dexamethasone test showed a negative result. Basal concentration of progesterone was found repeatedly mildly elevated $(0.8 \mathrm{ng} / \mathrm{ml})$. Post-ACTH stimulation concentration of progesterone was highly elevated $(8 \mathrm{ng} / \mathrm{ml})$.

Table 2. Haematological and biochemical values in the presented dog after trilostane therapy

\begin{tabular}{|l|c|c|}
\hline Parameter (unit) & $\begin{array}{c}\text { Presented } \\
\text { Patient }\end{array}$ & Reference range \\
\hline Haemoglobin $(\mathrm{g} / \mathrm{l})$ & 141 & $120-180$ \\
\hline Haematocrit $(\mathrm{l} / \mathrm{l})$ & 0.43 & $0.37-0.55$ \\
\hline Erythrocytes $\left(10^{12} / \mathrm{l}\right)$ & 6.28 & $5.4-8.0$ \\
\hline Leukocytes $\left(10^{9} / \mathrm{l}\right)$ & 9.2 & $0-18$ \\
\hline Neutrophils bands $\left(10^{9} / \mathrm{l}\right)$ & 0.276 & $3-11.4$ \\
\hline Neutrophils mature $\left(10^{9} / \mathrm{l}\right)$ & 5.428 & $0.8-3.8$ \\
\hline Lymphocytes $\left(10^{9} / \mathrm{l}\right)$ & 2.392 & $0-1.8$ \\
\hline Monocytes $\left(10^{9} / \mathrm{l}\right)$ & 0.276 & $0-1.9$ \\
\hline Eosinophils $\left(10^{9} / \mathrm{l}\right)$ & 0.828 & $55-75$ \\
\hline Total protein $(\mathrm{g} / \mathrm{l})$ & 60 & $23-34$ \\
\hline Albumin $(\mathrm{g} / \mathrm{l})$ & 27 & $3.3-7$ \\
\hline Glucose $(\mathrm{mmol} / \mathrm{l})$ & 5.5 & $20-110$ \\
\hline Creatinine $(\mu \mathrm{mol} / \mathrm{l})$ & 97.7 & $3-9$ \\
\hline Urea $(\mathrm{mmol} / \mathrm{l})$ & 8 & $0.1-2.5$ \\
\hline ALP $(\mu \mathrm{kat} / \mathrm{l})$ & 1.4 & $0-1$ \\
\hline ALT $(\mu \mathrm{kat} / \mathrm{l})$ & 0.4 & $0-1$ \\
\hline AST $(\mu \mathrm{kat} / \mathrm{l})$ & 0.2 & $0.5-1.7$ \\
\hline Triglycerides $(\mathrm{mmol} / \mathrm{l})$ & 0.6 & $2.7-7.0$ \\
\hline Cholesterol $(\mathrm{mmol} / \mathrm{l})$ & 3.5 & $140-158$ \\
\hline Sodium $(\mathrm{mmol} / \mathrm{l})$ & 148 & $3.8-5.8$ \\
\hline Potassium $(\mathrm{mmol} / \mathrm{l})$ & 4.3 & $2.2-2.9$ \\
\hline Calcium $(\mathrm{mmol} / \mathrm{l})$ & 2.5 & $0.5-2.6$ \\
\hline Phosphorus $(\mathrm{mmol} / \mathrm{l})$ & 0.8 & not determined \\
\hline Estradiol $(\mathrm{pmol} / \mathrm{l})$ & 85 & not determined \\
\hline Progesterone $(\mathrm{ng} / \mathrm{l})$ & $<0.4$ & depends on the phase of the ovarian cycle \\
\hline Post ACTH stimulation \\
progesterone $(\mathrm{ng} / \mathrm{ml})$
\end{tabular}

Ultrasonographic examination of adrenals and ovaries did not reveal any pathological signs. The first treatment option recommended and subsequently completed was ovariohysterectomy. Histopathological examination of ovaries did not show any pathological abnormality. Three months later, the owner reported considerable improvement, the dog was almost covered with hair and the quality of hair distinctly improved. The patient reappeared six month later, showing almost the same dermatological 
symptoms, which were however of a more striking character than before ovariohysterectomy and their intensity was increased. Again a series of examinations was carried out: heamatological and biochemical examinations, and hormonal tests. The results were almost identical with those of the first visit findings of the patient. Significant differences from the norm (increase) were found only with the basal and post ACTH stimulation concentrations of progesterone (basal progesterone $0.8 \mathrm{ng} / \mathrm{ml}$ and post ACTH stimulation $8.4 \mathrm{ng} / \mathrm{ml}$ ). Considering the course of disease (a temporary reaction to therapeutic castration) and hormonal test results, the final diagnosis determined the disease as an adrenal sex hormone imbalance.

The available therapy alternatives were proposed to the owner, and comparisons of their effectiveness were provided in detail, including descriptions of possible risks and undesirable side effects. The trilostan therapy was recommended as an effective and safe method for treatment of this disease. The owner agreed and the trilostan therapy was initiated. The initial trilostan dosage $8 \mathrm{mg} / \mathrm{kg} / \mathrm{day}$ was divided and given 2 times daily. Monitoring of the patient consisted of determining UCCR (minimization of the risk of iatrogenic hypoadrenocorticism) and defining concentrations of progesterone pre- and postACTH stimulation.

Six weeks after the beginning of therapy, the dog's hair started to grow normally, and after four months a complete hair coat was restored (Fig. 4, Plate xy). When ACTH stimulation test was performed, the pre- and post-stimulation concentations of progesterone were within the reference range $(<0.4 \mathrm{ng} / \mathrm{ml})$. The initial dosage of trilostane was reduced from $8 \mathrm{mg} / \mathrm{kg}$ $/$ day to $6 \mathrm{mg} / \mathrm{kg} /$ day. At present, the dog is medicated with the same dose of trilostane and control monitoring is carried out once in 4 months.

\section{Discussion}

The aetiology of alopecia $\mathrm{X}$ remains obscure. This dysfunction of follicular growth may be a result of a genetically determined but unidentified hormonal imbalance and/or a change in receptor sensitivity at the hair follicle level. If the problem is primary disorder of the hair growth cycle, various stimuli (including different hormones) could draw hair follicles into the anagen phase (Paradis 2004). It was recently suggested that alopecia may be due to a mild but prolonged increase in basal cortisol concentration, instead of adrenal sex hormone imbalance (Cerundolo 2001). In case of the affected dogs, it refers to the defect of one of the adrenal enzymes (the deficiency of particularly 21-hydroxylase), which results in a partial defect as far as the synthesis of cortisol and aldosterone is concerned ( S chmeitzel and Lothrop 1990). This disorder is functionally replaced by an increased production of ACTH and by a hyperplasia of adrenal tissue, so a sufficient amount of cortisol and mineralocorticoids is produced. This process does not lead to insufficiency. However, the cost for this is an excessively increased production of adrenal steroids (Feldman and Nelson 2004; Brunclík et al. 2005). On the other hand, there are authors who preclude the mutation of the 21-hydroxylase gene as a possible cause of the adrenal sex hormone imbalance ( Takada et al. 2002).

Adrenal sex hormone imbalance is an endocrine disease with mostly dermatologic clinical symptoms. These symptoms usually do not have impact on the general state of patient's health.

This patient was presented with typical signs of the disease: primarily non-pruritic alopecia near the genitals, further spreading cranially. The hyperpigmentation was presented.

The diagnosis of this disease is based on history, physical examination findings, ruling out other diseases (e.g. hypothyroidism and hyperadenocorticism, functional gonadal neoplasm, sebaceous adenitis, telogen effluvium and other follicular dysplasias), skin 
biopsies and response to therapy (Paradis 2004). The determination of sex hormones and their precursors is further recommended. If no differences in basal concentration are apparent, it is advisable to measure the concentration both before and after the application of the adrenocorticothropic hormone (Schemeitzel and Lothrop 1990; Scott et al. 1995). In case of the patient, the results of the above mentioned tests proved the basal and post-ACTH stimulation concentrations of progesterone to be significantly increased. Other results were within the reference range, thus allowing us to eliminate the presence of any other endocrine diseases.

Once other endocrine diseases have been ruled out, various medical and surgical treatments have been proposed. Castration is recommended. Most dogs will regrow a normal hair coat either permanently or for several months or several years (Paradis 2002, 2004). However, in case of the presented patient, its effect was only temporary and imperfect.

In neutered animals, various treatment modalities such as exogenous estrogen, testosterone or growth hormone can be administered. However, these therapies are no longer very popular because of cost, availability, adverse effects, and/or poor effectiveness (Paradis 2002, 2004).

O,p'-DDD (Lysodren ${ }^{\circledR}$ ) is a relatively effective alternative. The therapeutic dose is lower than when treating Cushing's disease. Owners must be well informed about the potential side effects (hypoadrenocorticism) before deciding for this treatment (Rosenkrantz 1992; Scott et al. 1995; Paradis 2002, 2004).

Recently, new drugs have been used in an attempt to stimulate hair regrowth in dogs with alopecia X. Leuprolide acetate, an antigonadothropin, has been used successfully in a dog with alopecia X. However, this drug is expensive and is only administered by intramuscular injection (Paradis 2002).

Melatonin has been used by several veterinary dermatologists over the last few years in a number of dogs with alopecia X. Melatonin given orally at the rate of $3-6 \mathrm{mg} \mathrm{q} 8-12 \mathrm{~h}$ for 3 months proved to be effective in approximately 30 - 50\% of the cases (Paradis 2004). Therefore, despite its modest success rate, melatonin is a valuable therapeutic alternative because of its safety and low cost. The hair growth observed in alopecic dogs treated with melatonin might be due to modulation of sex hormone levels, interference with cortisol production, action at the hair follicle level by blocking estrogen receptors (estrogen can inhibit anagen irritation) or actual melatonin deficiency (Paradis 2002).

Finasterid is as specific inhibitor of type II $5 \alpha$-reductase, an intracellular enzyme that converts testosterone to dihydrotestosterone, causing a significant decrease in serum and tissue dihydrotestosterone concentrations in both humans and dogs (Kaufman et al. 1998; Kamolpatana et al. 1998). Finasteride has no affinity for the androgen receptor and has no androgenic, estrogenic, antiestrogenic and progestational effects. The efficacy of finasteride in alopecia X is being assessed in a pilot study (Kaufman et al. 1998).

Trilostane, a competitive inhibitor of $\beta$-hydroxysteroid dehydrogenase, which interferes with adrenal steroidogenesis, has also shown encouraging results in Pomeranians and in miniature Poodles (Cerundolo et al. 2001). The principal effect of trilostane's inhibitory effect is an increase in pregnenolone, $17 \alpha-\mathrm{OH}$ pregnenolone, and dehydroepiandrostenedione, all of which are biologically inactive, and a decrease in cortisol and aldosterone. Trilostane has been shown to be very effective in treating dogs with hyperadrenocorticism (Neiger et al. 2002). Trilostane is rapidly absorbed from the gastrointestinal tract. Following oral administration of trilostane, peak plasma concentrations of trilostane occur after $0.5-1.5 \mathrm{~h}$ and return to near baseline levels in six hours. After oral administration of trilostane $\left(\right.$ Vetoryl $\left.{ }^{\circledR}\right)$ the plasma cortisol concentration is suppressed most significantly between 2 and $6 \mathrm{~h}$ after administration. Therefore, in order to obtain results at the peak time action, the ACTH stimulation test should be performed 2 - $3 \mathrm{~h}$ post dosing. 
In our patient, the trilostane therapy was used. The initial trilostane dosage $8 \mathrm{mg} / \mathrm{kg} / \mathrm{day}$ was divided and given 2 times daily. Four months after the beginning of therapy, this was reduced from 8 to $6 \mathrm{mg} / \mathrm{kg} / \mathrm{day}$. Treatment with trilostane led to complete hair regrowth in this dog within four months. No adverse effects associated with trilostane were recognized. Monitoring of the patient involved determining UCCR (minimization of the risk of iatrogenic hypoadrenocorticism) and defining concentrations of progesterone pre- and poststimulation ACTH. When ACTH stimulation test was performed during control examination, basal and post-stimulation concentrations of progesterone were within the reference range. Cerundolo et al. (2004) used trilostane for the treatment of canine alopecia $\mathrm{X}$ at a mean dose of $10.8 \mathrm{mg} / \mathrm{kg}$ two times daily in sixteen Pomeranians and eight miniature Poodles. Treatment with trilostane led to complete hair regrowth in $85 \%$ of the Pomeranians and in all of the miniature Poodles within 4 to 8 weeks. Leone et al. (2005) administered trilostane to treat alopecia $X$ at a dose $3 \mathrm{mg} / \mathrm{kg}$ two times daily to three Alaskan malamutes. Treatment led to complete hair re-growth in all three dogs within 6 months. No adverse effects associated with trilostane were recognized.

To conclude, it is possible to summarise that trilostane is effective and safe therapeutic option for the treatment of canine alopecia X.

\section{Využití trilostanu k terapii alopecie $X$ u amerického pitbulteriéra}

Práce popisuje př́ípad roční feny amerického pitbulteriéra, která byla prezentována s anamnézou progresivní ztráty srsti. Úvodní př́iznaky se projevovaly symetrickou, primárně nesvědivou alopecií, která začínala v perineální, genitální a ventrální abdominální oblasti a pokračovala kraniálně na hrudník a spodní část krku. Na základě klinického vyšetření, laboratorních výsledků, dermatologického vyšetření a výsledků kožní biopsie byla postavena diagnóza hormonální dermatóza. Po vyloučení hypotyreózy a hyperadrenokorticizmu byla s využitím hormonálních testů diagnóza specifikována jako alopecia X. První doporučenou a následně provedenou terapeutickou možností byla pro pacienta ovariohysterektomie. Tři měsíce po jejím provedení majitel konstatoval zlepšení, pes téměř zarostl. Pacient se znovu objevil za šest měsíců a vykazoval shodné dermatologické symptomy, které měly bohužel mnohem vážnější charakter než před provedením ovariohysterektomie. Znovu byla provedena série hormonálních vyšetření. Vzhledem ke zvýšené koncentraci bazálního progesteronu a zvýšené koncentraci progesteronu po stimulaci ACTH byla konečná etiologie onemocnění určena jako adrenální dysfunkce pohlavních hormonů. $Z$ tohoto důvodu byla zahájena terapie trilostanem. Denní dávka trilostanu $8 \mathrm{mg} / \mathrm{kg} \check{z}$. hm. byla dělena na dvě dílčí dávky. Terapie trilostanem vedla u psa $v$ průběhu čtyř měsíců k úplné obnově tělního pokryvu. Žádné vedlejší účinky jsme v průběhu terapie trilostanem nezaznamenali.

\section{References}

BRUNCLÍK V, KOLEVSKÁ J, BARTOŠOVÁ L 2005: A Case of Adrenal Sex Hormone Imbalance in a Dog. Acta Vet. Brno 74: 411-417

CERUNDOLO R, LLOYD DH, EVANS H, MOL JA, VAESSEN MMAR, KOOISTRA HS, RIJNBERK A. 2001: Alopecia in Pomeranians and miniature poodles is associated with mild pituitary-dependent hyperadrenocorticism. Proceeding of the International Symposium "Comparative Clinical Molecular Endocrinology". Utrecht, The Netherlands, pp. 29 -31

CERUNDOLO R, LLOYD DH, PERSECHINO A, EVANS H, CAUVIN A 2004: Treatment of canine Alopecia $\mathrm{X}$ with trilostane. Vet Dermatol 15: 285-93

FELDMAN EC, NELSON RW 2004: Disorders that resemble GH- responsive dermatosis. In: FELDMAN EC, NELSON RW. Canine and Feline Endocrinology and Reproduction. W. B. Saunders Comp., Philadelphia, pp. 64-69

KAMOLPATANA K, JOHNSTON SD, HARDY SK 1998: Effect of finasteride on serum concentrations of dihydrotestosterone and testosterone in three clinically normal sexually intact adult male dogs. Am J Vet Res 58: $762-764$ 
KAUFMAN KD, OLSEN EA, WHITING D, SAVIN R, DeVILLEZ R 1998: Finasteride in the treatment of men with androgenic alopecia. J Am Acad Dermatol 39: 578-589

LEONE F, CERUNDOLO R, VERCELLI A, LLOYD DH 2005: The Use of Trilostane for Treatment of Alopecia $\mathrm{X}$ in Alaskan Malamutes. J Am Anim Hosp Assoc 41: 336-342

NEIGER R, RAMSEY I, O'CONNOR J, HURLEY KJ, MOONEY CT 2002: Trilostane treatment of 78 dogs with pituitary-dependent hyperadrenocorticism. Vet Rec 150: 799-804

PARADIS M 1999: Melatonin-responsive alopecia in dogs. $15^{\text {th }}$ Proceedings of AAVD/ACVD Meeting, Maui, Hawaii. pp. 123-130

PARADIS M 2002: Alopecia X. Derm Dialogue. Summer, pp. 12-14

PARADIS M 2004: Canine alopecia: Hormonal or not? X. Proceedings of 5th WCVD, Vienna, Austria. pp. $157-172$

RIJNBERK A, WEES A, MOL JA 1988: Assessment of two tests for the diagnosis of canine hyperadrenocorticism. Vet Rec 122: 178-180

ROSENKRANTZ WS, GRIFFIN C 1992: Lysodren therapy in suspect adrenal sex hormone dermatosis. Proceedings of the Second World Congress of Veterinary Dermatology, Montreal, Canada, May, pp. 121-125

SCHMIETZEL LP, LOTHROP CD 1990: Hormonal abnormalities in Pomeranians with normal coat and in Pomeranians with growth hormone-responsive dermatosis. J Am Vet Med Assoc 197: 1333-1341

SCHMIETZEL LP 1999: Alopecia X of Nordic Breeds. $15^{\text {th }}$ Proceedings of AAVD/ACVD Meeting, Maui, Hawaii. pp. 131-138

SCOTT DW, MILLER WH, GRIFFIN CE 1995: Adrenal sex hormone imbalance. In: SCOTT DW, MILLER WH, GRIFFIN CE (Eds): Small Animal Dermatology. W. B. Saunders Comp., Philadelphia, pp. 688-690 